\title{
O trabalho do contador: um estudo realizado em instituições federais de ensino de Santa Catarina
}

Esta pesquisa objetiva caracterizar a percepção dos contadores a respeito do trabalho que realizam em Instituições Federais de Ensino de Santa Catarina (IFE/SC) e sua contribuição para gestão e sociedade. Os sujeitos da pesquisa são 41 (quarenta e um) contadores lotados e em exercício nas IFE/SC. Esta pesquisa apoia-se em uma abordagem metodológica qualitativa e como instrumento para coleta de dados utilizou-se a estratégia do questionário. Dessa forma, elaborou-se o instrumento de coleta de dados com o intuito de identificar o nível de formação dos contadores das IFE/SC, bem como o tempo de atuação nas instituições; a compreensão do contador a respeito do ofício realizado, do seu desenvolvimento profissional e sobre a contabilidade; e a percepção do contador acerca do espaço que a contabilidade possui na instituição e quanto à participação do contador na gestão da instituição e na sociedade. Para realizar a análise de conteúdo, fez-se uso da observação categorial descrita por Bardin (2009), que organiza as categorias a partir da totalidade do texto. A fim de dar suporte às considerações utilizaramse os principais autores MOW (1987), Migliaccio Filho (1994), Silva (2003), Alves et al. (2007), Tolfo et al. (2007), Tonin et al. (2007), Cardoso et al. (2006) e Slomski et al. (2010). Das respostas verificadas, identificaram-se as prerrogativas da ocupação do contador, haja vista que as atividades desempenhadas estão centradas na forte presença de uma rotina em que se evidencia um trabalho mecanizado, repetitivo cuja premissa está centrada na individualização e não na compreensão de todo o processo de trabalho. Apesar da ênfase na repetição, as respostas apontam para o trabalho executado, para a primazia pelo conhecimento técnico e para ética no que se realiza, ainda que esta direcione ao que se realizou. Quanto ao desenvolvimento profissional, as respostas indicam a formação continuada centrada em práticas contábeis rotineiras. Em relação ao espaço que a contabilidade ocupa nas instituições, a compreensão dos contadores é que esse espaço cresce e que os serviços desempenhados pelo contador contribuem para a tomada de decisão da gestão. Desse modo, verifica-se que os profissionais compreendem o produto do trabalho realizado e os benefícios reais para as instituições. Entretanto, os resultados apontam que os contadores possuem dificuldades para compreender o alcance do serviço para a sociedade, e isso impacta no sentido do valor que esse tem para o profissional.

Palavras-chave: Trabalho; Contador; Instituições Federais de Ensino.

\section{The work of the accountant: a study conducted in federal educational institutions of Santa Catarina}

\begin{abstract}
This research aims to characterize the accountants' perception of the work they perform in Federal Teaching Institutions of Santa Catarina (IFE / SC) and their contribution to management and society. The survey subjects are 41 (forty-one) full-time accountants in the IFE / SC. This research is based on a qualitative methodological approach and as a tool for data collection the questionnaire strategy was used. Thus, the instrument of data collection was elaborated with the intention of identifying the level of training of accountants of the IFE / SC, as well as the time of performance in the institutions; the accountant's understanding of the job done, their professional development and accounting; and the accountant's perception of the space that accounting has in the institution and the participation of the accountant in the management of the institution and in society. To perform the content analysis, we made use of the categorical observation described by Bardin (2009), who organizes the categories from the totality of the text. In order to support the considerations, the main authors MOW (1987), Migliaccio Filho (1994), Silva (2003), Alves et al. (2007), Tolfo et al. (2007), Tonin et al. (2007), Cardoso et al. (2006) and Slomski et al. (2010). From the verified answers, the prerogatives of the accountant's occupation were identified, since the activities performed are centered in the strong presence of a routine in which a mechanized, repetitive work is evidenced whose premise is centered in the individualization and not in the comprehension of all the work process. Despite the emphasis on repetition, the answers point to the work performed, to the primacy of technical knowledge and to ethics in what is done, even if it leads to what has been accomplished. Regarding professional development, the responses indicate the continuing training centered on routine accounting practices. Regarding the space that accounting occupies in the institutions, the accountants' understanding is that this space grows and that the services performed by the accountan contribute to the decision making of the management. In this way, it is verified that professionals understand the product of the work done and the real benefits for the institutions. However, the results point out that accountants have difficulties in understanding the reach of the service to society, and this impacts in the sense of the value that this has for the professional.
\end{abstract}

Keywords: Work; Accountant; Federal Educational Institutions.

Topic: Gestão Pública

Reviewed anonymously in the process of blind peer.

Laís Karine Sardá Martins

Universidade Federal de Santa Catarina, Brasil

http://lattes.cnpq.br/7046161436253901

lais-karine@hotmail.com

\section{Marcos Laffin (iD)}

Universidade Federal de Santa Catarina, Brasil

http://lattes.cnpq.br/3230734469709272

http://orcid.org/0000-0003-3204-3817

marcoslaffin@gmail.com

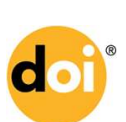

DOI: 10.6008/CBPC2179-684X.2018.001.0007
Received: 11/01/2019

Approved: 21/04/2019

\section{Referencing this:}

MARTINS, L. K. S.; LAFFI, M.. O trabalho do contador: um estudo realizado em instituições federais de ensino de Santa Catarina. Revista Brasileira de Administração Científica, v.9, n.1, p.93-114, 2018. DOI: http://doi.org/10.6008/CBPC2179-684X.2018.001.0007 


\section{INTRODUÇÃO}

O mundo do trabalho tem passado por grandes e importantes modificações. Elas decorreram, principalmente, do surgimento de novas tecnologias as quais fizeram com que a forma de pensar e de organizar o trabalho dentro das organizações também se modificasse. Araújo et al. (2007) relatam que, segundo os aspectos históricos e políticos, a humanidade estrutura-se em torno do conceito de trabalho. Para os autores, o homem, desde o caçador da era paleolítica até o trabalhador da área técnico-científica informacional do século XXI, percebe o trabalho como razão de viver. Desse modo, verifica-se a força que o trabalho, como forma de gerar a vida humana, possui nas relações construídas histórica e politicamente, muito mais do que a própria manutenção, mas além de produzir o trabalho e o produto dele, modifica também o modo de viver.

Diante desse contexto, o trabalho passa de realização própria individual para humana coletiva e vaise ampliando ao longo do tempo em diferentes contextos históricos, pelos quais se evidencia a relevância das discussões que envolvem este estudo. As transformações nas relações de trabalho, principalmente devido ao avanço tecnológico, afetaram as diversas áreas de atuação do mercado de trabalho e fizeram com que os trabalhadores se adaptassem e, simultaneamente, aprendessem acerca da nova realidade.

Entre as diversas áreas de atuação do mercado de trabalho insere-se a contabilidade como uma das áreas que sofreu grandes modificações na forma de realizar o trabalho. A inovação tecnológica foi um marco na alteração da prática contábil, pois por meio dela tornou-se possível a utilização de sistemas informatizados que permitem os lançamentos contábeis, a geração de relatórios e a elaboração de demonstrações contábeis de forma tempestiva. Para Oliveira et al. (2011), o profissional contábil precisa adaptar-se às novas tecnologias que surgem na área de maneira constante e deve cultivar ainda a capacidade de se atualizar diante das inovações relacionadas à contabilidade. Contudo, as novas tecnologias e as formas de realizar o trabalho contábil não destituem a essência de conhecimentos e de práticas que se voltam às diferentes maneiras de controle do patrimônio.

Nesse contexto, a contabilidade possui como uma das principais características o fato de a atuação do contador ser marcada de constantes práticas contábeis, que ao longo do tempo se fizeram convencionais e conservadoras, induzindo um pensamento e uma forma de agir com constante preocupação dos discentes em aprender a fazer. Decorrente desta preocupação uma das principais críticas feita por docentes e discentes é o fato de o ensino universitário ser excessivamente teórico (CAPACCHI et al., 2007), como se as referências teóricas fossem expressões tácitas de prescrições que se traduzem em práticas universais. Desse modo, surge a disfunção entre a teoria e a prática na formação do contador. Para Kraemer (2005), a prática nos cursos de ciências contábeis, quando existe, está limitada a um ou dois semestres no laboratório de informática ou à participação em Empresa Júnior. Assim, apesar de a teoria e a prática serem complementares, há certa dificuldade do encontro delas no ambiente acadêmico.

Essa dificuldade de interação entre teoria e prática surge no ambiente acadêmico durante a formação do profissional, mas se perpetua para o ambiente de trabalho influenciando na forma como o contador 
compreende o trabalho realizado. Marin et al. (2014) ao relacionarem as necessidades do mercado de trabalho com a formação do contador verificaram que segundo a percepção dos gestores os contadores ao ingressarem no mercado de trabalho possuem um vasto conhecimento teórico, mas dificuldades de visão prática na aplicação dos conceitos aprendidos em sala de aula. Historicamente, o currículo do curso de ciências contábeis é composto majoritariamente por disciplinas da área de ciências sociais aplicadas, visando a uma formação para a aplicação de conhecimentos, restringindo-se de disciplinas curriculares com ênfase na crítica e no questionamento do mundo e nas práticas sociais, apesar da Resolução n. 10 CNE/CES n. 10, de 16 de dezembro de 2004 permitir a flexibilidade curricular este se mantém alicerçado na racionalidade instrumental.

Assim, a percepção sobre a relação teoria e prática no trabalho do contador, que separa o trabalho manual do intelectual, é percebida na formação do contador e na atuação deste profissional no mercado de trabalho. Esse entendimento possui relação direta com a forma com que o trabalhador compreende o sentido e o significado do trabalho. Sendo esses oriundos de uma historicidade, relacionando-se com a época, com a cultura e com o modo de se conviver e compreender o mundo na visão do sujeito e do meio em que está inserido (ARAÚJO et al., 2007).

Nesse contexto, verifica-se como o trabalhador compreende o ofício pautado nos aspectos sociais, econômicos e culturais. Tal compreensão quanto à percepção do contador em relação ao trabalho que executa está condicionada a diversos fatores como o espaço que ele tem na vida deste profissional, o processo formativo ao qual ele teve acesso e os aspectos sociais e culturais do meio que o cerca.

Considerando o trabalho como uma atividade central nos processos de desenvolvimento humano, individual e coletivo e, sendo a contabilidade uma área de atuação profissional inserida no cenário de desenvolvimento social, é inegável a necessidade de se ter percepções sobre o trabalho desenvolvido pelo contador, no sentido de dimensionar a atuação e a participação social.

O trabalho do contador envolve diversos aspectos, tais como: o registo, reconhecimento, evidenciação, mensuração, controle patrimonial e o fornecimento de informações que apoiem a tomada de decisão dos gestores. Destaca-se que a profissão possibilita que o contador atue em diversas áreas, podendo o profissional atuar em empresas, como autônomo, no ensino e nos órgãos públicos (MARION, 2003). No Brasil, a Resolução CFC n. 560/83 apresenta um conjunto de funções, cargos e titulações atribuídas ao profissional da área contábil, dentre elas encontra-se a de contador público (CFC, 1983).

O contador público é o profissional que realiza a contabilidade em instituições públicas, tendo em vista que a Lei n. 4.320/64 que estatui normas gerais de direito financeiro para elaboração e controle dos orçamentos e dos balanços da União, dos Estados, dos Municípios e do Distrito Federal estabelece que é de competência de a contabilidade demonstrar os fatos que envolvem a administração orçamentária, patrimonial, financeira e industrial (BRASIL, 1964). Essa pesquisa tem como foco a atuação do contador em entidades pertencentes à União, mais especificamente às autarquias federais vinculadas ao poder executivo. As autarquias federais são instituições criadas por lei, que possuem personalidade jurídica, receita e patrimônio próprios, e gestão financeira e administrativa descentralizada (BRASIL, 1967). Desse modo, a 
contabilidade das autarquias é realizada dentro de cada instituição sendo indispensável o cargo de contador responsável pela evidenciação dos atos e dos fatos contábeis.

Nesse contexto, o presente estudo porta-se ao tema o trabalho do contador em Instituições Federais de Ensino de Santa Catarina (IFE/SC). Haja vista que as referidas instituições possuem uma dupla correlação com o tema trabalho. $\mathrm{O}$ primeiro aspecto consiste no fato de as instituições possuírem autonomia financeira e patrimonial, bem como a contabilidade destas autarquias é realizada dentro do órgão sob responsabilidade técnica do contador lotado na Instituição. O segundo aspecto consiste no fato de as instituições de ensino serem responsáveis pela formação de profissionais de diversas áreas incluindo a área de ciências contábeis. Consequentemente, o trabalho dos contadores nas instituições de ensino evidencia uma dupla correlação com a propagação dos conhecimentos os quais são adquiridos na academia, na instituição formativa.

Partindo dessas premissas e para que seja possível compreender a percepção do contador a respeito do trabalho realizado, é necessário que se voltem as atenções para as atividades desenvolvidas por esses profissionais bem como para o produto do trabalho contábil. Dessa forma, definiu-se a seguinte pergunta de pesquisa para este estudo: Qual a percepção dos contadores a respeito do trabalho que realizam em Instituições Federais de Ensino de Santa Catarina e sua contribuição para gestão e sociedade?

\section{REVISÃO TEÓRICA}

\section{Sentidos e significados do trabalho}

O trabalho possui uma posição central na sociedade e impacta diretamente nas relações humanas; tornando-se necessário compreender os significados e os sentidos dele. Haja vista que o estudo dos significados e dos sentidos do trabalho são amplos e praticados por diversos autores, sendo oriundos de uma historicidade, que os relaciona com a época, com a cultura e com o modo de compreender o mundo na visão do sujeito e do meio em que esse está inserido (ARAÚjO et al., 2007).

Um dos primeiros estudos que abordou o sentido do trabalho é de autoria de Hackman et al. (1975) e se relaciona com a qualidade de vida no ambiente de trabalho, bem como com o sentido que exerce. Os autores identificaram que a importância, a utilidade e a legitimidade do trabalho vinculam-se a três características: a variedade de tarefas que permite o uso de diversas competências a fim de que o trabalhador se identifique com a execução do trabalho; um trabalho não-alienante que permita o trabalhador discernir todas as etapas que o envolvem; e o retorno quanto ao desempenho nas atividades executadas (TOLFO et al., 2007).

$\mathrm{Na}$ literatura acadêmica, há diversos estudos a respeito da temática sentidos e significados do trabalho que apresentam a elaboração de modelos sobre o tema. Nesse contexto, o estudo que constituiu um marco foi desenvolvido pela equipe Meaning of Work International Research Team (MOW) em 1987. A equipe MOW está sediada no Canadá e realiza pesquisas internacionais investigando o sentido e a centralidade do trabalho desde a década de 1970, tendo em vista que considera sentidos e significados do 
trabalho como sinônimos, definindo baseados em estudos empíricos como: a centralidade do trabalho; as normas sociais sobre o assunto e os resultados valorizados do trabalho (TOLFO et al., 2007).

A dimensão centralidade do trabalho é conceituada por MOW (1987), como “o grau de importância geral que o trabalho tem na vida de um indivíduo para um dado ponto no tempo". Percebe-se que a centralidade absoluta evidencia a importância que o trabalho possui para a vida do sujeito; a centralidade relativa analisa se há ou não relação entre o trabalho e os demais momentos importantes da vida do sujeito. Assim, a centralidade do trabalho é constatada por meio da percepção do sujeito e da forma com o qual esse compreende o trabalho que executa.

A segunda dimensão apresentada por MOW (1987) denomina-se normas sociais sobre o trabalho. Elas são provenientes de valores morais relacionados a ele e que antecedem princípios e condutas sociais vinculados aos deveres e aos direitos dos trabalhadores (TOLFO et al., 2007). Nesse contexto, os deveres são percebidos como padrões sociais vistos de maneira geral como corretos e que devem ser adotados pelo indivíduo em relação à sociedade. Os direitos, por sua vez, são as obrigações que a sociedade apresenta para com o indivíduo (MOW, 1987). Percebe-se que as relações de trabalho envolvem deveres e direitos, assim, o trabalhador deve executar suas atividades, visando contribuir para a sociedade como um todo e, por sua vez, a sociedade na figura do estado ou do empregador deve garantir ao sujeito um trabalho significante.

A terceira dimensão apontada por MOW (1987) são os resultados valorizados do trabalho. Segundo Tolfo et al. (2007), esta dimensão trata dos “(...) valores relacionados com as finalidades que as atividades representam para a pessoa, respondendo à indagação acerca dos motivos que a levam trabalhar". Essa dimensão abrange o que o sujeito busca no trabalho, as funções que o trabalho cumpre na vida do sujeito e as necessidades supridas por meio dele (TOLFO et al., 2007). Dessa maneira, verificam-se que os valores relacionados ao trabalho têm interferência cultural e são estabelecidos durante a infância e a adolescência do sujeito, mas sofrem modificações e interferências no decorrer da formação profissional do indivíduo, destacando-se que o sentido do trabalho se relaciona com a forma com que as atividades são executadas, a produtividade e a versatilidade do sujeito (MOW,1987).

Diante do exposto, percebe-se que o trabalho se associa com a realidade social predominante em determinado local e período. Assim, para que a vida tenha sentido é necessário que o sujeito encontre na profissão sua realização, pois não há possibilidade de ter uma vida ampla de sentido se, no trabalho, o indivíduo não encontra sentido algum (ANTUNES, 2000).

Tais estudos a respeito dos sentidos e dos significados do trabalho estão presentes na literatura acadêmica, tendo sido aplicados a trabalhadores que exercem as mais variadas profissões, inclusive na área contábil e financeira. A pesquisa de Caproni Neto (2012) identificou e analisou o sentido e o significado do trabalho para funcionários do setor contábil-financeiro de uma Instituição de Ensino Superior (IES) pública a partir do modelo desenvolvido por MOW (1987) e os achados evidenciam que os referidos profissionais consideram o trabalho como uma esfera significativa em suas vidas, enfatizando-o com atividade geradora de valor que permite retorno financeiro e contribuição para com a sociedade. 


\section{Prerrogativas da profissão contábil e demandas da profissão no âmbito das IFE}

A regulamentação da profissão de contador no Brasil iniciou-se por meio do Decreto n. 20.158, de 30 de junho de 1931, sendo que ele trata, no Título III, da Profissão de Contador e das suas regalias e dispõe nos artigos 53 e 54 que são considerados contadores os portadores de certificados de auxiliar do comércio e dos diplomas de perito-contador, guarda-livros, administrador-vendedor, atuário, secretário e bacharel em ciências econômicas, expedidos pelos estabelecimentos de ensino comercial, reconhecidos oficialmente (BRASIL, 1931).

Posteriormente, publicou-se o Decreto-Lei n. 9.295, de 27 de maio de 1946, que dispõe sobre a criação do Conselho Federal de Contabilidade, o qual define as atribuições do contador e do guarda-livros, dando-lhe outras providências. A Lei n. 12.249 de 11 de junho de 2010 alterou o Decreto-Lei n. 9.295/46 e estabeleceu que os profissionais tratados no referido Decreto só exercerão a profissão contábil mediante a conclusão de Bacharelado em Ciências Contábeis em curso regularmente reconhecido pelo Ministério da Educação (MEC), aprovação em Exame de Suficiência e registro no Conselho Regional de Contabilidade da região competente (BRASIL, 2010). O Decreto n. 9.295/46 criou o Conselho Federal de Contabilidade (CFC) e estabeleceu atribuições profissionais para o profissional contábil. Com a Criação do CFC, o referido Decreto (BRASIL, 1946) estabelece também a instituição dos Conselhos Regionais de Contabilidade (CRC) e dispõe que os CRC's são responsáveis por esclarecer dúvidas acerca das atribuições profissionais do profissional contábil, cabendo ao CFC decidir em última instância a respeito da matéria. Diante do exposto, em 28 de outubro de 1983 o CFC resolve detalhar as atribuições profissionais dispostas no Decreto n. 9.295/46 por meio da publicação de Resolução CFC n. 560/83 apresentando, assim, as atribuições privativas do profissional de contabilidade.

No âmbito das IFE, a Lei n. 11.091 de 12 de janeiro de 2005 dispõe sobre a estruturação do Plano de Carreira dos Cargos Técnico-administrativos em Educação, no âmbito das Instituições Federais de Ensino vinculadas ao Ministério da Educação e dá outras providências. Com base na Referida Legislação, o Ministério da Educação (MEC) elaborou o Ofício Circular n.015/2005/CGGP/SAA/SE/MEC destinado às Instituições Federais de Ensino, o anexo do referido ofício apresenta a descrição dos cargos técnico-administrativos em educação, que foram autorizados pelo Ministério de Planejamento, Orçamento e Gestão para concurso público. Cabe destacar que o ofício elaborado pelo MEC apresenta as prerrogativas da profissão de contador, sendo que cada instituição possui suas particularidades e, como consequências, formas específicas de organizar o trabalho.

\section{METODOLOGIA}

Nesta seção, evidenciam-se os aspectos metodológicos norteadores da pesquisa. Quanto a abordagem metodológica definiu-se a qualitativa para o presente estudo, sendo a escolha pela pesquisa qualitativa, por se relaciona ao fato de o estudo objetivar a caracterização das percepções sobre o trabalho 
do contador que o configura em seus significados para a vida e sua intervenção social, assim, deseja-se desvelar o que constitui o trabalho do contador tendo como centralidade e constituição de trabalhador.

Em relação à natureza, a pesquisa é classificada como aplicada, pois visa gerar conhecimento investigando especificamente o trabalho do contador em instituições de ensino público. Quanto aos procedimentos técnicos, a pesquisa enquadra-se como documental e empírica. A documental faz uso de documentos que foram elaborados com diversas finalidades, tais como: documentos institucionais, comunicações, instrucionais, entre outros (GIL, 2010). Já está pesquisa trata da "face empírica e factual da realidade; produz e analisa dados, procedendo sempre pela via do controle empírico e fatual" (DEMO, 2000). Assim, este estudo buscou nas legislações e normas pertinentes informações que versam sobre as prerrogativas do trabalho do contador. O estudo utiliza ainda da empiria, pois a coleta de dados realizou-se por meio da aplicação de questionário junto aos contadores visando conhecer a vivência desses nas instituições pesquisadas.

Além disso, o estudo utiliza a técnica do levantamento, pois há a aplicação de questionário com os contadores que trabalham nas instituições objeto deste estudo. Destaca-se que a pesquisa de levantamento mostra o dado como ele é, assim, as análises e as inferências do pesquisador é que vão dimensionar as respostas, já o campo empírico definido para a aplicação do estudo são as IFE/SC. Conceituou-se as IFE/SC como campo para a realização da pesquisa pelo fato de elas serem autarquias federais de ensino, possuindo assim similaridade quanto à organização administrativa, financeira e contábil, propiciando a investigação a respeito do trabalho do contador.

Como instrumento de coleta de dados, disponibilizou-se aos contadores das IFE/SC um questionário, o qual foi elaborado pela pesquisadora e submetido à pré-teste com contadores de autarquias federais não participantes da pesquisa, resguardando-se o anonimato deles, sendo ele elaborado com o intuito de identificar: o nível de formação dos contadores das IFE/SC e o tempo de atuação nas instituições; a compreensão do contador a respeito do trabalho realizado, da contabilidade e do seu desenvolvimento profissional; e a percepção do contador a respeito do espaço que a contabilidade possui na Instituição e quanto à participação do contador na gestão da instituição e na sociedade. O questionário foi elaborado por meio da ferramenta de formulários on-line do Google e encaminhado por e-mail para os contadores das IFE/SC. A análise e a compreensão das respostas dos contadores basearam-se na análise de conteúdo na perspectiva de Bardin (2009), que se constitui como "um conjunto de técnicas de análise das comunicações visando obter por procedimentos sistemáticos e objetivos de descrição do conteúdo das mensagens indicadores (quantitativos ou não) que permitam a inferência de conhecimentos relativos às condições de produção/recepção (variáveis inferidas) destas mensagens".

Para realizar a análise do conteúdo, fez-se uso da análise categorial descrita por Bardin (2009), que organiza as categorias de análise a partir da totalidade do texto. A definição das categorias de análise foi assumida a partir da 'frequência de presença (ou de ausência) de itens de sentido', a partir do material de análise composto pelos questionários respondidos pelos contadores das IFE/SC. Sendo o primeiro passo da análise foi a organização do material, na qual, as respostas obtidas foram sintetizadas a partir dos elementos 
que explicitavam o sentido do discurso, a partir da condensação das falas, os elementos semelhantes foram agrupados dando origem às categorias de análise. Após a etapa de categorização, realizaram-se as inferências e as interpretações a partir dos dados coletados.

A pesquisa foi realizada com as quatro instituições federais de ensino do Santa Catarina, essas são as seguintes: Instituto Federal de Educação Ciência e Tecnologia de Santa Catarina (IFSC), Instituto Federal de Educação, Ciência e Tecnologia Catarinense (IFC), Universidade Federal de Santa Catarina (UFSC) e Universidade Federal da Fronteira Sul (UFFS). Os sujeitos da pesquisa são os contadores lotados e em exercício nas Instituições Federais de Ensino de Santa Catarina (IFE/SC). Nos meses de junho e julho de 2017, solicitou-se ao setor de gestão de pessoas das Instituições estudadas a listagem contendo nome completo e e-mail institucional dos contadores da Instituição.

Desse modo, com base nas informações obtidas junto ao setor competente de cada instituição, foram enviados via e-mail aos contadores das quatro instituições estudadas questionário solicitando a participação na pesquisa. O questionário foi aplicado no período de 11 de julho de 2017 a 10 de outubro de 2017 . 0 questionário foi enviado para 83 (oitenta e três) contadores que estavam em exercício nas IFE/SC em 2017. Desses, 47 (quarenta e sete) responderam às questões solicitadas. Dentre os respondentes foi verificado por meio dos dados coletados que seis (6) não desempenham as atividades de contador na instituição, assim, como o foco do estudo é o trabalho do contador as respostas destes profissionais foram desconsideradas nesta dissertação. Deste modo, analisaram-se os questionários respondidos por 41 contadores.

Destaca-se que na análise de cada pergunta são evidenciados o número de respondentes que mantiveram resposta coerente com a pergunta formulada, além de ressalta que os 41 questionários analisados tiveram todas as questões respondidas, contudo, nem sempre com coerência em relação à questão formulada; dessa forma, optou-se por validar por cada questão as respostas obtidas. Os contadores participantes da pesquisa estão caracterizados na análise de resultados por 'Q1, Q2, Q3' .

\section{RESULTADOS E DISCUSSÃO}

Os resultados da pesquisa foram organizados em três subseções. As respostas de cada pergunta foram organizadas por categorias, sendo apresentadas como elementos de textos as respostas que representam de maneira completa cada um dos grupos.

\section{Formação dos contadores e tempo de atuação na IFE/SC}

Nesta seção, são demonstrados os dados obtidos por meio de três questionamentos feitos aos contadores participantes da pesquisa. O primeiro é a 'Qual a instituição e ano de formação no curso de ciências contábeis?'. Essa questão teve 39 respostas válidas, pois dois respondentes não responderam o que foi perguntado. O Gráfico 1 apresenta os dados referente às instituições formadoras. 


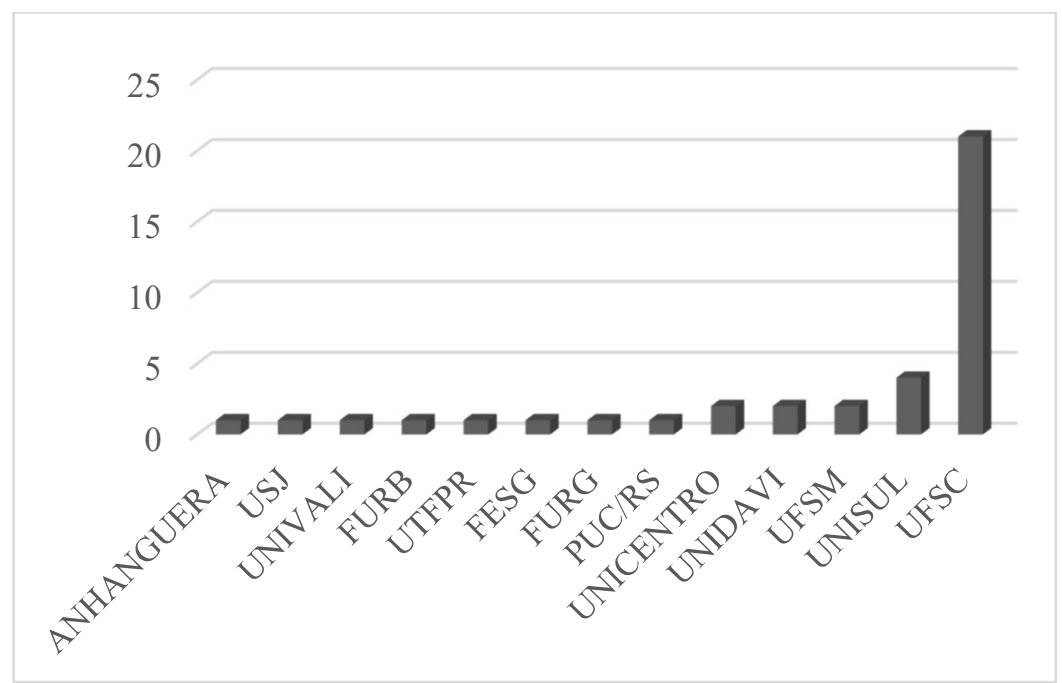

Gráfico 1: Instituição de formação no Curso de Ciências Contábeis.

De acordo com o Gráfico 1, verificou-se que a formação em ciências contábeis dos participantes da pesquisa está distribuída em 13 universidades. Destaca-se que a Universidade Federal de Santa Catarina foi a instituição responsável pela formação de 21 profissionais. Além da instituição de formação, questionou-se o ano de formação do profissional, que está evidenciado no Gráfico 2.

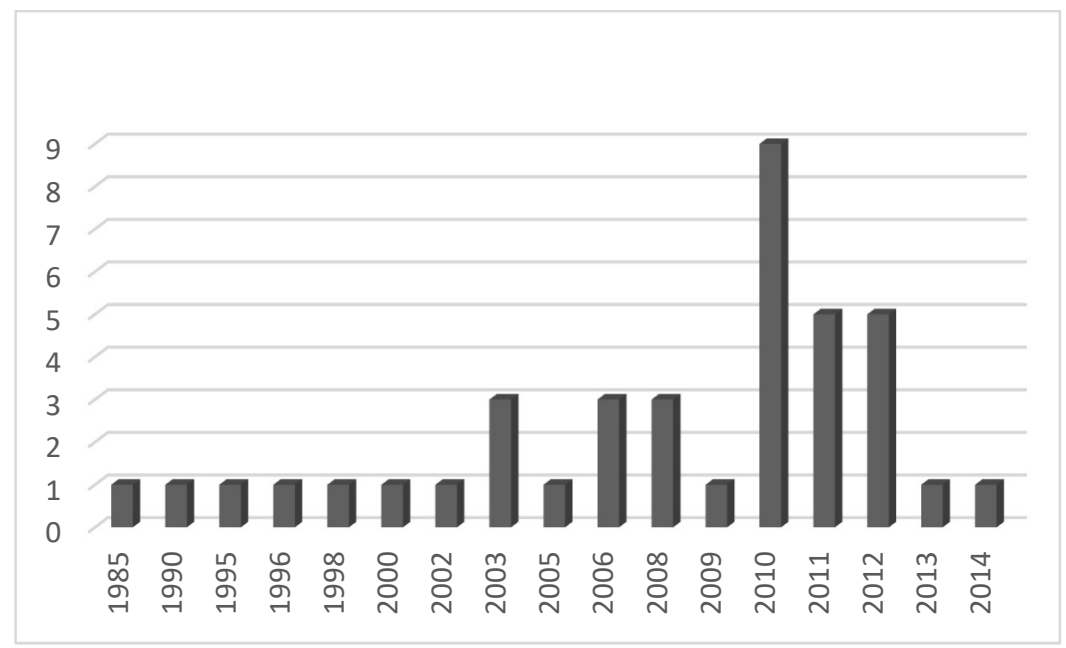

Gráfico 2: Ano de formação no Curso de Ciências Contábeis.

Conforme o Gráfico 2, constatou-se que dos 39 contadores que responderam à questão, 21 concluíram o curso de graduação em ciências contábeis no período que compreende os anos de 2010 a 2014. A segunda questão desta seção aborda os aspectos formativos da profissão por meio do seguinte questionamento: Fez algum curso de formação continuada relacionado à atividade que você desempenha? Qual? Qual nível?.

Essa questão, obtiveram-se 41 respostas válidas e constatou-se que seis (6) contadores relataram não terem participado de cursos de formação continuada; dessa forma, 35 contadores informaram a participação em cursos com tais características. O Gráfico 3 apresenta os tipos de cursos de formação continuada informado pelos respondentes da pesquisa. 


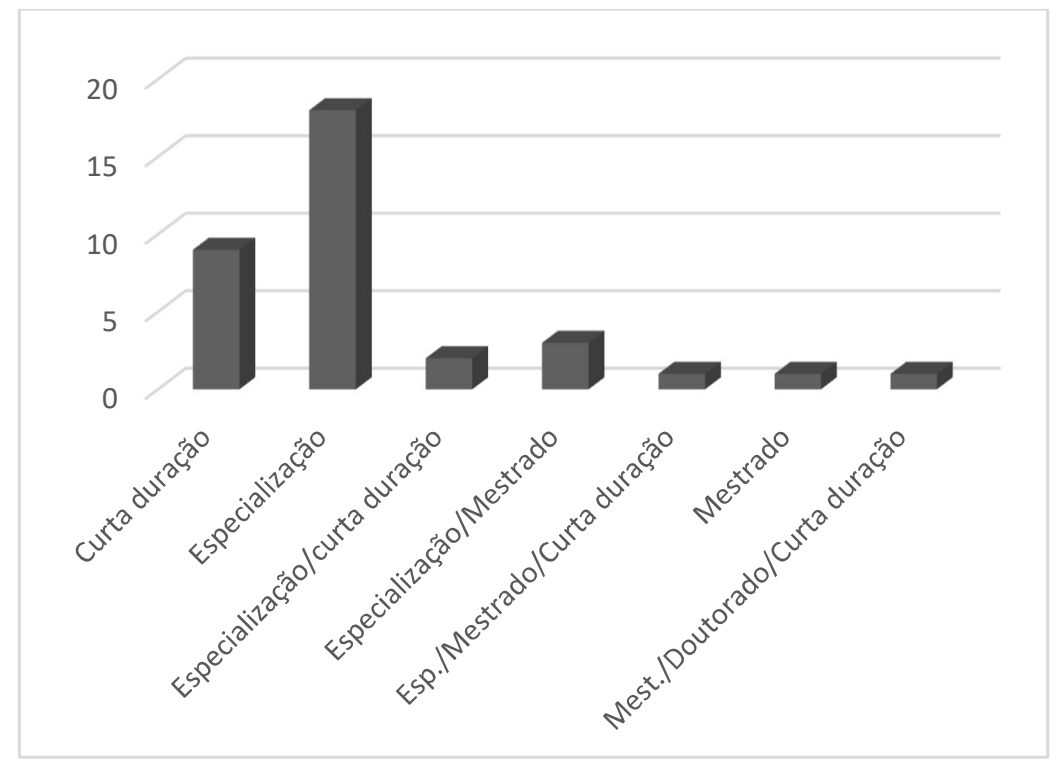

Gráfico 3: Cursos de Formação continuada.

De acordo com o Gráfico 3, identificou-se que dos 35 (trinta e cinco) contadores que participaram de cursos de formação continuada 18 (dezoito) realizaram cursos de especialização, 9 (nove) cursos de curta duração, 3 (três) cursos de especialização, mestrado e doutorado, 2 (dois) cursos de especialização e curta duração, 1(um) curso de especialização, mestrado e curta duração, 1 (um) curso de mestrado, doutorado e curta duração, 1 (um) curso de mestrado. Cabe destacar que os cursos de curta duração informado pelos respondentes da pesquisa trata-se de cursos, oficinas, palestras e seminários organizados pela própria instituição em que trabalham, órgão superior e escolas do governo.

Por fim, a última pergunta dessa seção questionou-se o tempo de atuação do contador, tendo em vista que se fez a seguinte pergunta: Há quanto tempo você trabalha exercendo a atividade de contador na instituição? Essa pergunta teve 40 (quarenta) respostas válidas, pois um contador respondeu à questão de forma incompleta. Na Tabela 1 demonstra o tempo de atuação dos profissionais participantes da pesquisa no cargo de contador nas instituições estudadas.

Tabela 1 - Tempo de atuação dos contadores na IFE/SC.

\begin{tabular}{|l|l|}
\hline Tempo de atuação & Número de Contadores \\
\hline De 0 a 3 anos & 14 \\
\hline De 3 anos e 1 dia a 6 anos & 20 \\
\hline De 6 anos e 1 dia a 9 anos & 4 \\
\hline De 9 anos e 1 dia a 12 anos & 1 \\
\hline De 12 anos e 1 dia a 20 anos & 1 \\
\hline
\end{tabular}

Conforme consta na Tabela 1, verifica-se que 26 (vinte e seis) contadores responderam que atuam nas instituições a mais de três anos. Assim, 14 (quatorze) dos pesquisados trabalham nas IFE/SC há menos de três anos. A seção seguinte tem como foco as questões que abordaram o trabalho do contador e o desenvolvimento profissional deles.

\section{0 trabalho do contador e o desenvolvimento profissional}


Esta seção apresenta as respostas das questões que tratam da compreensão do contador a respeito do trabalho realizado, da contabilidade e do seu desenvolvimento profissional. Desse modo, a presente seção contém as respostas de nove perguntas contidas no questionário. A primeira questão desse tópico é a seguinte: Como você define contabilidade?. Dos 41 (quarenta e um) respondentes da pesquisa, 35 (trinta e cinco) responderam o que foi perguntado na questão.

As respostas obtidas foram organizadas em categorias, conforme Quadro 1. Destaca-se que os grupos emergem das respostas expostas e representam a totalidade da amostra, sendo selecionadas, uma vez que melhor traduzem as respostas, mantendo coerência e fidelidade discursiva.

Quadro 1: Definição de contabilidade.

\begin{tabular}{|l|l|}
\hline Categorias & Elementos do texto \\
\hline $\begin{array}{l}\text { Essencial para gestão } \\
\text { da Instituição }\end{array}$ & $\begin{array}{l}\text { Ferramenta para auxiliar na gestão e na administração das organizações. A administração pública gira } \\
\text { em torno da contabilidade, desde a criação do orçamento até a execução da despesa e se ela for } \\
\text { empregada da forma correta, ela traz inúmeras informações que nos auxiliam na maximização e na } \\
\text { otimização do dinheiro público (Q22). }\end{array}$ \\
\hline $\begin{array}{l}\text { Controla o patrimônio } \\
\text { e apoio à tomada de } \\
\text { decisão }\end{array}$ & $\begin{array}{l}\text { Contabilidade é a ciência que objetiva o estudo das variações quantitativas e qualitativas ocorridas no } \\
\text { Patrimônio (conjunto de bens, direitos e obrigações) das entidades. Por meio dela é fornecido o máximo } \\
\text { de informações úteis para as tomadas de decisões, tanto dentro quanto fora da empresa, estudando, } \\
\text { interpretando, registrando e controlando o Patrimônio (Q2). }\end{array}$ \\
\hline $\begin{array}{l}\text { Responsável pela } \\
\text { execução } \\
\text { trabalhos realizados dos }\end{array}$ & $\begin{array}{l}\text { A contabilidade é definida como execução de diversos trabalhos na área, análises, classificações } \\
\text { contábeis, lançamentos, pagamentos (Q37). }\end{array}$ \\
\hline $\begin{array}{l}\text { Complexa e atrelada a } \\
\text { burocracia. }\end{array}$ & $\begin{array}{l}\text { Ciência social difícil de ser aplicada em sua totalidade. Para muitos, uma ciência exata, com precisões e } \\
\text { exatidões. Para nós, profissionais, complexa e interpretável (Q15). }\end{array}$ \\
\hline
\end{tabular}

Conforme o Quadro 1, a primeira categoria contemplou as respostas que definiram a contabilidade como essencial à gestão e essa foi a percepção de 11 (onze) dos contadores. A segunda vinculou a contabilidade ao controle do patrimônio e a tomada de decisão, sendo a compreensão de 19 (dezenove) dos respondentes, já a terceira evidenciou a contabilidade como responsável pela execução dos trabalhos realizados e representa 3 (três) dos contadores e a quarta categoria aponta a contabilidade como complexa e atrelada à burocracia, correspondendo às respostas de 2 (dois) dos respondentes da questão.

Observa-se que os resultados vincularam, quase que em sua totalidade, o conceito de contabilidade ao controle patrimonial e ao apoio à tomada de decisão; entretanto, elaboraram-se as definições de maneira reprodutiva sem que houvesse relação direta entre o conceito elaborado e a presença da contabilidade no ambiente de trabalho desses profissionais. Para Slomski et al. (2010), "a visão dominante de ciência é regida por um rigoroso determinismo e privilegia o 'como fazer' em detrimento do 'por que fazer'”. Essa visão de 'como fazer', disseminada nos processos formativos, encontra-se presente na compreensão dos contadores a respeito do conceito de contabilidade. Dessa forma, observa-se nas respostas a manutenção dos conceitos veiculados na academia, uma vivência pragmática do fazer. Não foram encontrados indicativos de que a atuação pelo conceito traduza formas de pensar a instituição senão aquela que adita o já prescrito. A próxima questão desta seção é a seguinte: Descrever as atividades que você desempenha na instituição. Essa questão teve 40 respostas válidas, sendo categorizadas, conforme Quadro 2.

De acordo com o Quadro 2, a primeira categoria contempla as atividades que envolvem os estágios da despesa, repactuação de contratos, controle orçamentário, pareceres contábeis, estas atividades são 
desempenhadas por 21 (vinte e um) dos respondentes; a segunda apresenta as atividades relacionadas a regularizações contábeis, conformidade contábil e de gestão, emissão de pareceres contábeis, lançamentos contábeis, análise de planilhas de formação de preços, e correspondem às atividades realizadas por 14 (quatorze) contadores; a terceira categoria trata-se de atividades vinculadas à folha de pagamento e aos cálculos trabalhistas e expressam as atividades executadas por 2 (dois)respondentes; a quarta trata-se do controle e da conciliação de contas de almoxarifado/patrimônio e entrega de declarações e representa a resposta de 2 (dois)contadores e, por fim, a quinta categoria é a prestação de contas de contratos, essa categoria contempla as atividades desempenhadas por 1 (um) dos respondentes.

Quadro 2: Atividades desempenhadas na Instituição.

\begin{tabular}{|c|c|}
\hline Categorias & Elementos do texto \\
\hline $\begin{array}{l}\text { Estágios da despesa, repactuação de } \\
\text { contratos, controle orçamentário, pareceres } \\
\text { contábeis. }\end{array}$ & $\begin{array}{l}\text { Empenho. Liquidação. Pagamento. Repactuação contratos. Elaboração de } \\
\text { planilhas de controles orçamentários e financeiros (Q5). }\end{array}$ \\
\hline $\begin{array}{l}\text { Regularizações contábeis, conformidade } \\
\text { contábil e de gestão, emissão de pareceres } \\
\text { contábeis, lançamentos contábeis, análise de } \\
\text { planilhas de formação de preços. }\end{array}$ & $\begin{array}{l}\text { Análise da conformidade diária do SIAFI (notas de lançamento, notas de } \\
\text { empenho, notas de dotação; ordens bancárias; GPS; DARFs); análise mensal da } \\
\text { documentação das empresas terceirizadas referente ao recolhimento dos } \\
\text { encargos sociais e trabalhistas (conferência da GFIP, GPS, GRF); cálculo e } \\
\text { controle das retenções dos tributos federais e municipais incidentes sobre as } \\
\text { notas fiscais; conferência e ajustes referentes às movimentações realizadas pelo } \\
\text { setor de almoxarifado e patrimônio; cálculo e recolhimento do PASEP sobre } \\
\text { receita própria; análise de planilhas de formação de preços das empresas } \\
\text { terceirizadas e seus respectivos ajustes e reajustes; lançamentos contábeis } \\
\text { (depreciação, baixas, ajustes)-(Q26). }\end{array}$ \\
\hline Folha de pagamento e cálculos trabalhistas & Contabilização e pagamento de folha de pessoal (Q2). \\
\hline $\begin{array}{l}\text { Controle e conciliação de contas de } \\
\text { almoxarifado/patrimônio e entrega de } \\
\text { declarações }\end{array}$ & $\begin{array}{l}\text { Conciliação e controle mensal das contas de almoxarifado e patrimônio. Registro } \\
\text { de baixas e incorporações de bens imobilizado. Classificação dos bens } \\
\text { intangíveis. DIRF (Q15). }\end{array}$ \\
\hline Prestação de contas de contratos & $\begin{array}{l}\text { Atualmente trabalho com a prestação de contas dos contratos (muitos deles } \\
\text { derivados de convênios) da UFSC com as fundações de apoio, com a emissão de } \\
\text { parecer técnico-contábil relativo aos documentos fiscais apresentados, } \\
\text { observando os normativos legais, no sentido de auxiliar na tomada de decisão } \\
\text { do Conselho de Curadores (Q40). }\end{array}$ \\
\hline
\end{tabular}

Inicialmente, destaca-se que as atividades descritas pelos contadores estão alinhadas com as atribuições da profissão contidas na Resolução CFC n. $560 / 83$ e no ofício circular n. 015/2005/CGGP/SAA/SE/MEC emitido pelo Ministério da Educação (MEC). Desse modo, as atividades executadas pelos pesquisados tratam-se de atribuições inerentes ao cargo.

Ressalta-se, ainda, por meio das descrições apresentadas, que o trabalho desempenhado é voltado às atividades de execução, que expressam a forte presença da prática contábil e de uma rotina de trabalho. As respostas coletadas concordam com os estudos de Silva (2003), Cardoso et al. (2006), Almeida et al. (2007), que ao pesquisarem a respeito do perfil profissional do contador exigido pelo mercado de trabalho constataram que a busca por profissionais que tenham o perfil de um 'guarda-livros' ainda é superior ao profissional 'parceiro de negócio'. Por fim, ressalta-se a forte presença de uma rotina de trabalho e de atividades voltadas para a execução. Esses aspectos são indicativos de um trabalho mecanizado, repetitivo cuja premissa está centrada na individualização das atividades e não na compreensão de todo o processo de trabalho. 
Além da descrição das atividades solicitadas, fez-se o seguinte questionamento aos contadores: Como você define o trabalho que realiza? Essa questão teve 27 (vinte e sete) respostas válidas, pois 14 (quatorze) participantes não apresentaram coerência em suas respostas. As respostas foram categorizadas, conforme Quadro 3.

Quadro 3: Definição do trabalho realizado

\begin{tabular}{|l|l|}
\hline Categorias & Elementos do texto \\
\hline Operacional & $\begin{array}{l}\text { Na contabilidade, exerço um trabalho objetivo, focado e profissional, entretanto, devido às atribuições } \\
\text { dos contadores no IFSC, as atividades são extremamente operacionais (Q6). }\end{array}$ \\
\hline $\begin{array}{l}\text { Importante para a } \\
\text { Instituição }\end{array}$ & Importante e indispensável na gerência dos recursos e do orçamento da Instituição (Q29). \\
\hline Burocrático & Burocrático demais e sem a devida autonomia (Q30). \\
\hline Gratificante & Gratificante, possibilita uma grande obtenção de aprendizado e experiência (Q35). \\
\hline
\end{tabular}

Nessa questão, dos 27 (vinte e sete) respondentes 17 (dezessete) definiram o trabalho como importante para a instituição, 6 (seis) relataram o trabalho que realizam como operacional, 2 (dois) como burocrático e 2 (dois) como gratificante. Ressalta-se que as respostas apresentadas evidenciam o sentido e o significado que o trabalho possui na vida do sujeito. As respostas contidas tanto na categoria "importante para a instituição" quanto 'gratificante' se aproximam do exposto no estudo MOW (1987) que relaciona o sentido do trabalho a três dimensões: a centralidade do trabalho, as normas sociais sobre ele e os resultados valorizados por ele (TOLFO et al., 2007).

$\mathrm{Na}$ categoria 'importante para a instituição', os contadores expressam em suas respostas a importância do seu trabalho para a organização e para a sociedade. Na categoria 'gratificante', os pesquisados apresentam o sentido do trabalho para o indivíduo. Relacionando às dimensões apresentadas por MOW (1987) com as respostas identificadas na categoria 'importante para a instituição' e 'gratificante' constata-se a presença da centralidade do trabalho na vida do pesquisado, principalmente na categoria 'gratificante', pois ao sentir-se gratificado com o trabalho executado o contador evidencia o quão importante é o trabalho para sua vida.

A dimensão normas relacionadas ao trabalho também estão presentes nas respostas apresentadas nas duas categorias, por meio da evidenciação de direitos e deveres. Os direitos aparecem nas respostas que apontam a ampliação do conhecimento e a experiência, afinal, o indivíduo tem direito a um trabalho interessante e que permite atualizar-se constantemente. Os deveres estão descritos nas respostas que expressam a importância do trabalho para a instituição e para a sociedade, pois é dever do sujeito contribuir para o bem social. Por fim, a dimensão denominada resultados valorizados no trabalho relaciona-se às motivações c que os trabalhadores buscam no trabalho. Dessa forma, ao definirem o trabalho como importante, gratificante e propulsor de conhecimento, os contadores relatam alguns dos resultados alcançados por meio do ofício realizado. Diante do exposto, as categorias são 'importantes para a instituição' e 'gratificantes' apresentam nas respostas dos participantes da pesquisa o sentido que o trabalho possui para eles.

Ainda em relação à definição do trabalho, cabe analisar o conjunto de respostas apresentadas nas categorias denominadas 'operacional' e 'burocrático', e essa percepção foi apresentada por oito dos 
respondentes. Haja vista que o trabalho operacional "é aquele que segue regras fixas e conhecidas e apresenta resultados, pelo menos, estatisticamente seguros" (MIGLIACCIO FILHO, 1994). Assim, o trabalho realizado de maneira operacional não permite que o sujeito reflita a respeito da atividade desempenhada. Tolfo et al. (2007) abordam que "a partir do momento em que a tarefa se torna rotineira, burocrática, operacional e incapaz de instigar seu executor, influencia diretamente na definição de um trabalho que faz ou deixa de ter sentido para o sujeito". Desse modo, os contadores ao definirem o trabalho executado como operacional e burocrático não apontaram reflexões a respeito dele, uma vez que não há evidenciação do sentido que ele possui para o sujeito.

A próxima questão apresentada nessa seção é para que indique seis características/atributos profissionais que você considera essencial para o trabalho do contador em instituições federais de ensino. Essa questão teve 40 (quarenta) respostas validas. A Tabela 2 apresenta os seis atributos que se destacaram dentre as indicações dos participantes da pesquisa.

Tabela 2: Características/atributos profissionais essencial para o trabalho do contador.

\begin{tabular}{|l|l|}
\hline Características/Atributos & Número de Contadores \\
\hline Conhecimento técnico & 23 \\
\hline Ética & 20 \\
\hline Capacidade de atualizar-se constantemente & 15 \\
\hline Comprometimento & 9 \\
\hline Organização & 9 \\
\hline Responsabilidade & 9 \\
\hline
\end{tabular}

As características/atributos de destaque foram conhecimento técnico, ética, capacidade de atualizarse constantemente, comprometimento, organização e responsabilidade. Destaca-se, ainda, que as características/atributos indicados pelos pesquisados corroboram os estudos de Biasibetti et al. (2017) e Tonin et al. (2017) que ao estudarem o perfil profissional, estereótipos e habilidades do contador constataram que o conhecimento técnico e a ética estão no ranking das seis principais características que os contadores reconhecem no seu perfil profissional.

Ao indicarem os atributos conhecimento técnico e ética como essenciais, os contadores evidenciam como o processo formativo que tiveram acesso influencia na forma como eles compreendem o trabalho realizado. As respostas apresentadas corroboram o texto contido na Resolução CNE/CES n. 10, de 16 de dezembro de 2004 que determina as habilidades e as competências mínimas que o curso de ciências contábeis, por meio da formação profissional, deve possibilitar destacando o domínio do conhecimento técnico e o exercício da profissão com base na ética (BRASIL, 2004). A academia, por meio dos processos formativos, aborda o que é aceitável em termos de formação e conhecimento contábil, o contador, por sua vez, capta essas prerrogativas apresentadas e organiza o seu trabalho com base nelas.

A quinta questão apresentada nesse tópico relaciona o código de ética profissional com as atividades realizadas, conforme segue: Como o código de ética da profissão é integrado nas atividades que você desempenha na Instituição? Esse questionamento teve 34 (trinta e quatro) respostas válidas. 0 Quadro 7 apresenta as respostas organizadas por categorias. 
Quadro 4: Integração do código de ética com as atividades desempenhadas.

\begin{tabular}{|l|l|}
\hline Categorias & Elementos do texto \\
\hline Integração & $\begin{array}{l}\text { Acredito que o código de ética imprime uma conduta moral e profissional, tanto do profissional contábil } \\
\text { como dos servidores públicos, no caso dos contadores da UFSC. Portanto, há uma perfeita integração, uma } \\
\text { vez que a responsabilidade do contador pelos documentos que assina ou atividades que executa são tão } \\
\text { relevantes dentro como fora da instituição (Q9). }\end{array}$ \\
\hline $\begin{array}{l}\text { Integração } \\
\text { mediana }\end{array}$ & $\begin{array}{l}\text { Busco fazer as atividades que me são atribuídas, mas sempre registro o que não é possível ser feito e o que } \\
\text { não é feito e a Instituição precisa fazer. Apesar de não ser o suficiente, é uma maneira que utilizo para } \\
\text { registrar a preocupação com a ética na atividade em que exerço (Q15). }\end{array}$ \\
\hline Integração baixa & $\begin{array}{l}\text { Baixa, uma vez que o desempenho de rotinas contábeis é pouco, mas o que tem está sempre relacionado } \\
\text { ao código de ética (Q8). }\end{array}$ \\
\hline
\end{tabular}

Destaca-se que 29 (vinte e nove) dos contadores percebem a integração do código de ética com as atividades desempenhadas como alta, 2 (dois) como mediana e 3 (três) como baixa ou pouco integrada. Assim, 82,85\% dos pesquisados compreendem que o código de ética profissional está integrado ao trabalho realizado. Os resultados coletados corroboram aos achados de Alves et al. (2007) que ao investigar a importância do código de ética para o profissional contábil concluiu que nem todos os profissionais que consideram o código de ética como um guia de conduta importante e estão predispostos a segui-lo.

A questão seguinte tem como foco a relação teoria-prática com as atividades executadas, fazendose a seguinte pergunta: Como você analisa a questão da relação teoria-prática em suas atividades profissionais? Para essa questão considerou-se 32 (trinta e duas) respostas, pois, 9 (nove) participantes não responderam o que foi pedido na questão. Os resultados estão organizados por categorias e foram evidenciadas as respostas que representam melhor cada categoria, conforme exposto no Quadro 5.

Quadro 5: Relação teoria-prática nas atividades profissionais

\begin{tabular}{|l|l|}
\hline Categorias & Elementos do texto \\
\hline Unicidade & Teoria e prática estão inteiramente ligadas. Não há prática sem a teoria (Q4). \\
\hline Dicotomia & Na prática a realidade é bem diferente da teoria (Q16). \\
\hline
\end{tabular}

A compreensão dos contadores quanto à relação teoria-prática das atividades desempenhadas foi organizada em duas categorias. Portanto, 18 (dezoito) dos contadores perceberam que há unicidade na relação teoria-prática, ou seja, que há integração entre a teoria e a prática durante a realização das atividades; já 14 (quatorze) destacaram a relação teoria-prática como dicotômica, não percebendo integração entre elas.

Os resultados apresentados nos questionários evidenciaram que os contadores apontaram a relação teoria e prática tanto com unicidade quanto com dicotomia. Evidenciou-se que a teoria é a indicação prescrita em conceitos, normas, regulamentos. Já a prática é resultante dos manuais e se revela no momento de realização das atividades. Desse modo, as respostas que apresentam a unidade entre teoria e prática, as quais representam o entendimento de 18 (dezoito) dos respondentes, contêm a presença da dicotomia nas entrelinhas. Essas respostas apresentam uma frágil percepção quanto à interação entre teoria e prática, conforme se observou nos argumentos expostos pelo contador 24 (vinte e quatro): "acredito que o conhecimento teórico é fundamental para a correta aplicação prática. Contudo, nem sempre as situações teóricas são facilmente aplicáveis no cotidiano, visto que neste há implicação de outros fatores, muitas vezes, imprevisíveis na teoria (Q24)". 
Consequentemente, percebe-se que a unicidade apresentada na resposta aponta como a relação teórico-prática deveria estar presente nas atividades, mas não de fato como essa interação realmente ocorre. Assim, no momento da execução do trabalho os profissionais sentem dificuldades em constatarem a interação entre a teoria e a prática, surgindo a presença da dicotomia na resposta apresentada. Nesse contexto, evidencia-se que a dicotomia entre teoria e prática é a característica marcante nas atividades desempenhadas pelos contadores nas IFE/SC, e isso indica ainda insatisfação na apropriação do trabalho.

A próxima questão é: Quais formas utiliza para atualizar os conhecimentos contábeis necessários para a sua atividade profissional?. Essa questão foi respondida por todos os participantes da pesquisa. 0 Quadro 6 apresenta as respostas obtidas por categorias.

Quadro 6: Formas de atualização do conhecimento contábil.

\begin{tabular}{|l|l|}
\hline Categorias & Elementos do texto \\
\hline Cursos/Treinamentos/Capacitações & $\begin{array}{l}\text { Realização de cursos de curta duração presencial e a distância, participação em } \\
\text { congresso e palestras, reuniões (Q15). }\end{array}$ \\
\hline Cursos/leituras/pesquisas na internet & $\begin{array}{l}\text { Cursos EAD, periódicos de organizações da Categoria (Sindicatos/Conselho), leitura de } \\
\text { novas legislações (Q21). }\end{array}$ \\
\hline Apenas leitura de legislação e materiais & $\begin{array}{l}\text { A principal ferramenta que utilizo é a Internet. Leitura e estudo do Manual de } \\
\text { Contabilidade Aplicada ao Setor Público (7a Edição), Macrofunções, Legislação (Q11). }\end{array}$ \\
\hline $\begin{array}{l}\text { Curso/pesquisas/discussões com } \\
\text { colegas }\end{array}$ & $\begin{array}{l}\text { Leitura de legislação, participação em palestras, minicursos e encontros relacionados à } \\
\text { temática que envolve a administração e a contabilidade pública; troca de experiências } \\
\text { com profissionais de outras instituições; discussão com colegas de trabalho (Q14). }\end{array}$ \\
\hline Autodidata & Mediante conhecimento autodidata (Q12). \\
\hline $\begin{array}{l}\text { Acompanhamento de fóruns e debates } \\
\text { via e-mail. }\end{array}$ & Acompanho fóruns contábeis e debates de grupos de e-mail (Q10). \\
\hline
\end{tabular}

Quanto às formas de atualização do conhecimento contábil, as respostas obtidas possuem a seguinte representação: 15 (quinze) informaram que se atualizam por meio de cursos, leituras e pesquisas na internet; 12 (doze) por meio de cursos, treinamentos e capacitações; 7 (sete) mediante cursos, pesquisas e discussões com colegas; 5 (cinco) exclusivamente por meio de leitura de legislações e demais materiais; 1 (um) por meio do conhecimento autodidata; e 1 (um) acompanha fóruns e debates via e-mail. Os resultados obtidos com essa questão remetem à discussão dos processos formativos no âmbito da educação continuada. Junqueira aborda que

(..) educação continuada não poderia ser confundida com treinamento, reciclagem, aperfeiçoamento ou capacitação, isto porque a educação continuada como geradora de mudanças insere-se num quadro político prospectivo, em que formação é idealmente participar do futuro a partir do presente, e assumir o risco para formar é mudar de forma que pode implicar deformar! Mas o que devemos considerar de vital importância é ter sempre presente que educação continuada não é apenas transmissão de conhecimentos científicos, mas, também, de atitudes em relação à utilização desses conhecimentos (JUNQUEIRA, citado por BITTENCOURT, 2006).

Desse modo, as respostas dos pesquisados apresentam a formação continuada centrada nas práticas da rotina de trabalho, portanto, as atualizações a que os profissionais tiveram acesso foram voltadas à transmissão de conhecimento não havendo indicadores que demonstrem alteração na maneira de produzir o trabalho.

A última pergunta dessa seção tratou do desenvolvimento quanto à atuação profissional do contador, fazendo-se o seguinte questionamento: a partir da sua experiência e tempo de exercício exercendo 
a profissão de contador na Instituição, como você avalia o desenvolvimento da sua atuação na área contábil? Essa questão obteve 37 (trinte e sete) respostas válidas. O Quadro 7 apresenta as repostas obtidas organizadas em categorias.

Quadro 7: Desenvolvimento quanto a atuação na área contábil.

\begin{tabular}{|l|l|}
\hline Categorias & Elementos do texto \\
\hline $\begin{array}{l}\text { Bom, em constante } \\
\text { desenvolvimento }\end{array}$ & $\begin{array}{l}\text { Obtive muito conhecimento nos últimos dezenove meses de uma área que eu não conhecia: a } \\
\text { contabilidade pública. A conclusão que eu chego é que nunca sabemos tudo e temos que estar } \\
\text { constantemente em busca de aprendizado (Q4). }\end{array}$ \\
\hline Regular/Satisfatório & $\begin{array}{l}\text { Por ter ficado pouco tempo localizada no setor de contabilidade, avalio meu desenvolvimento como } \\
\text { mediano (Q17). }\end{array}$ \\
\hline $\begin{array}{l}\text { Não houve muito } \\
\text { desenvolvimento }\end{array}$ & Cumprir rotinas e procedimentos. Não há muito desenvolvimento (Q5). \\
\hline
\end{tabular}

Conforme exposto no Quadro 7, as respostas quanto ao desenvolvimento profissional foram organizadas em três categorias. Deste modo, 24 (vinte e quatro) respondentes consideram o seu desenvolvimento como bom e acreditam estar em constante desenvolvimento, 9 (nove) evidenciaram como regular ou satisfatório e 4 (quatro) acreditam que não houve muito desenvolvimento profissional.

Identificou-se nas respostas apresentadas a presença de desenvolvimento profissional e aprendizado em virtude também da inserção dos pesquisados na área pública. Dessa forma, percebe-se que há estado de abertura para o novo dentro da área. Contudo, o novo é o que vem de normas, regulamentos e leis. Consequentemente, verificou-se que a rotina e a operacionalidade tomam corpo de trabalho como sentido de reprodução desse.

\section{Contabilidade e atuação profissional na IFE/SC e sociedade}

Essa seção apresenta as respostas das questões que tratam da percepção do contador a respeito da importância da contabilidade para a Instituição e da participação do profissional na gestão e na sociedade. A primeira questão desse tópico é a seguinte: Qual espaço/importância a contabilidade ocupa na Instituição?. Essa questão teve 38 (trinta e oito) respostas válidas. O Quadro 8 apresenta as respostas obtidas organizadas por categorias.

Quadro 8: Espaço/Importância da Contabilidade para a Instituição.

\begin{tabular}{|l|l|}
\hline Categorias & Elementos do texto \\
\hline $\begin{array}{l}\text { Pouco } \\
\text { espaço/importância }\end{array}$ & $\begin{array}{l}\text { Como um ponto obrigatório, mas não muito importante, os questionamentos feitos são para } \\
\text { solucionar problemas já existente, não para melhorar situações no futuro (Q22). }\end{array}$ \\
\hline $\begin{array}{l}\text { Espaço/importância } \\
\text { mediana }\end{array}$ & $\begin{array}{l}\text { Está conseguindo mais espaço por meio de grupos de trabalhos dos contadores, da elaboração de } \\
\text { manuais de padronização entre os campi, porém ainda enfrenta algumas resistências (Q17) }\end{array}$ \\
\hline Grande importância & $\begin{array}{l}\text { Acredito que possuem grande importância, visto que sem o planejamento efetuado na contabilidade } \\
\text { seria difícil controlar os gastos (Q10). }\end{array}$ \\
\hline
\end{tabular}

Conforme Quadro 8, as respostas quanto ao espaço/importância da contabilidade para a instituição foram organizadas em três categorias. Nesse contexto, 17 (dezessete) dos contadores consideram que a contabilidade é vista como pouco importante para a instituição, 11(onze) analisam como mediano o espaço ocupado pela contabilidade na Instituição e 10 (dez) perceberam que a contabilidade possui um grande espaço/importância para a instituição. 
A visão dos contadores a respeito do espaço que a contabilidade ocupa nas instituições evidenciaram que a maioria dos respondentes considera que a contabilidade possui pouco espaço nas instituições. Entretanto, as respostas que assinalaram o espaço da contabilidade como mediano e de grande importância demonstram a presença de mudanças nos espaços institucionais. Essas respostas se aproximam dos resultados apontados no trabalho de Brandalise et al. (2009) que ao questionar os gestores das prefeituras pertencentes a Associação dos municípios do Alto Uruguai a respeito da importância do setor contábil para a tomada de decisão da gestão evidenciou que os $67 \%$ dos gestores pesquisados atribuíram elevada importância ao setor contábil. Diante do exposto os achados, quanto à importância da contabilidade para as IFE/SC, assinalaram para um processo de mudança nos espaços institucionais; entretanto, a prática contábil obedece a prescrições de resultado restando poucas alternativas para mudar as rotinas de trabalho.

Além do espaço/importância da contabilidade para instituição fez-se o seguinte questionamento aos contadores das instituições: Como as atividades realizadas pelo contador contribuem para o desenvolvimento da Instituição? Essa questão teve 36 (trinta e seis) respostas válidas. As respostas estão categorizadas no Quadro 9.

Quadro 9: Contribuição das atividades realizadas para a Instituição.

\begin{tabular}{|l|l|}
\hline Categorias & Elementos do texto \\
\hline $\begin{array}{l}\text { Apoio a tomada de } \\
\text { decisão }\end{array}$ & $\begin{array}{l}\text { Contribuem de forma a organizar e gerenciar toda a parte de registros contábeis, correta aplicação } \\
\text { das legislações tributárias, gerenciamento de informações orçamentárias, contábeis, financeiras; e a } \\
\text { partir disso, permite planejar a melhor tomada de decisão por parte dos gestores (Q1). }\end{array}$ \\
\hline $\begin{array}{l}\text { Execução de atividades } \\
\text { operacionais }\end{array}$ & $\begin{array}{l}\text { Contribuem para a execução dos processos de forma a otimizar a utilização dos recursos disponíveis } \\
(\mathrm{Q} 8) .\end{array}$ \\
\hline $\begin{array}{l}\text { Cumprimento de } \\
\text { legislação e obrigações } \\
\text { acessórias }\end{array}$ & $\begin{array}{l}\text { O trabalho desenvolvido pelo profissional contábil traz segurança para os gestores, devido a } \\
\text { adequação às regras e às normas. Uma instituição bem amparada pelos profissionais contábeis tende } \\
\text { a ter menos problemas com órgãos fiscalizadores (Q13). }\end{array}$ \\
\hline
\end{tabular}

De acordo com o Quadro 9, apresentou como o contador relaciona as atividades exercidas por eles e a contribuição destas para a instituição. Desse modo, 21 (vinte e um) dos respondentes percebem que as atividades desempenhadas contribuem para a tomada de decisão dos gestores da instituição, 10 (dez) evidenciaram que as atividades exercidas contribuem para a execução das atividades operacionais de maneira adequada e 5 (cinco) acreditam que as atividades do contador propiciam à instituição o cumprimento das legislações pertinentes e das obrigações acessórias.

As respostas apresentadas nessa questão evidenciam como os contadores compreendem o produto do trabalho realizado. Percebe-se que apesar da realização de um trabalho rotineiro e prescritivo, a contabilidade alcança resultados efetivos na contribuição da gestão administrativa e financeira da instituição. Por conseguinte, tem-se a visão de que o trabalho do contador é útil apenas para o cumprimento de normas e legislações, embora a adequação das exigências estabelecidas pelos órgãos de controle passa a dar lugar a uma compreensão de trabalho que apresenta como produto benefícios reais para a instituição.

Haja vista que a maioria das respostas enfatiza que as atividades desenvolvidas contribuem para a tomada de decisão da gestão. Nesse aspecto, a próxima questão dessa seção é Como você descreve a participação do contador na gestão da instituição em que você trabalha?. Essa pergunta teve 36 (trinta e seis) respostas válidas. As repostas foram categorizadas, conforme Quadro 10. 
Quadro 10: Participação do contador na gestão da Instituição.

\begin{tabular}{|l|l|}
\hline Categorias & Elementos do texto \\
\hline $\begin{array}{l}\text { Participação } \\
\text { efetiva }\end{array}$ & $\begin{array}{l}\text { O Contador, no Campus em que atuo, desempenha um papel importante em razão de participar no processo } \\
\text { decisório da maioria das ações/gestões realizadas dentro do Departamento de Administração (DAM) da } \\
\text { Instituição do Campus (Q29). }\end{array}$ \\
\hline $\begin{array}{l}\text { Participação } \\
\text { baixa }\end{array}$ & $\begin{array}{l}\text { De pouco destaque uma vez que a gestão, por muitas vezes, vê apenas quanto poderá ser gasto e não analisa a } \\
\text { qualidade do gasto ou o impacto que esse pode produzir na gestão. No entanto, a contabilidade consegue prever } \\
\text { inúmeras situações e apresentar dados reais e provisionais para ajudar na tomada de decisão, mas atualmente } \\
\text { a contabilidade é utilizada para cumprir a norma e registrar os fatos já ocorridos (Q22). }\end{array}$ \\
\hline
\end{tabular}

O Quadro 10 apresenta as duas categorias que contemplam a percepção dos pesquisados quanto à participação do contador na gestão das instituições. Desse modo, 20 (vinte) dos respondentes caracterizaram como efetiva a participação do contador na gestão da IFE e 16 (dezesseis) evidenciaram como baixa a referida participação. As respostas coletadas na questão corroboram o estudo de Coelho (2001), que ao questionar profissionais contábeis a respeito do perfil profissional do contador evidenciou que a principal mudança se relaciona ao perfil e ao crescimento na participação desse profissional na gestão das organizações. Destacaram-se as respostas que apresentam a percepção do participante quanto à contribuição técnica na gestão. Tendo em vista que, por meio da aplicação dos saberes técnicos, toma-se corpo a importância da participação profissional na gestão.

A próxima questão dessa seção é Como você avalia a participação política do contador na sociedade a partir do trabalho de contador em instituições federais de ensino?. Essa questão teve 32 (trinta e duas) respostas válidas, sendo organizadas em duas categorias. O Quadro 11 apresenta as respostas categorizadas e as que melhor representam cada categoria.

Quadro 11: Participação política do contador na sociedade.

\begin{tabular}{|l|l|}
\hline Categorias & Elementos do texto \\
\hline Positiva & $\begin{array}{l}\text { A atuação do Contador e o trabalho de gerir os recursos financeiros do Campus com efetividade } \\
\text { contribui com a sociedade visto que dentro da instituição será proporcionado aos alunos um } \\
\text { ambiente/estrutura satisfatória que favoreça e contribua na formação desses cidadãos (Q29). } \\
\text { Positiva, você conhece a aplicação dos recursos na área da educação (Q32). }\end{array}$ \\
\hline $\begin{array}{l}\text { Pouco } \\
\text { representativa/baixa }\end{array}$ & $\begin{array}{l}\text { A participação política é muito pequena. O contador ainda é visto como "guarda-livros" ou "calculador } \\
\text { de impostos". A sociedade parece ainda não ter percebido as contribuições que o contador pode } \\
\text { proporcionar. O contador também parece não se interessar em mostrar que pode contribuir (Q15). } \\
\text { A participação política ainda é tímida. O contador que atua em IES consegue ter a visão dos recursos } \\
\text { destinados à educação de sua unidade orçamentária e, portanto, atuar em discussões políticas no que } \\
\text { tange a angariar recursos e projetos para que os gastos sejam melhor empregados (Q31). }\end{array}$ \\
\hline
\end{tabular}

Conforme o Quadro 11, as respostas referentes à participação política do contador na sociedade foram demonstradas a partir de duas categorias. Desse modo, 18 (dezoito) dos respondentes consideram pouco representativa ou baixa a participação política do contador na sociedade e 14 (quatorze) julgaram-na positiva. Portanto, a participação política do contador tem relação com a forma com que ele percebe o produto de seu trabalho e o valor desse para a sociedade. Nas respostas que evidenciaram a baixa participação política do contador, verificou-se a compreensão do produto do trabalho para a instituição, mas não houve a percepção dessa contribuição para a sociedade. Ponderando que as instituições em que os contadores atuam são mantidas por meio de recursos públicos, os benefícios reais que o trabalho do contador proporciona para a instituição estende-se à sociedade como um todo. 
Destaca-se, que a resposta do contador Quadro 11 evidencia a percepção que ele tem a respeito da imagem do contador para a sociedade. Outro aspecto presente na resposta está no fato de o respondente expressar a falta de interesse do profissional contábil em evidenciar as contribuições que o seu trabalho traz para a sociedade. Assim, constata-se que a preocupação do contador em executar as atividades diárias faz com ele não visualize o alcance do seu trabalho para com a sociedade e isso impacta no valor que o trabalho possui para esse profissional.

A segunda dimensão desenvolvida pela equipe por MOW (Meaning of Work Internacional Research Team) em 1987 trata das Normas Sociais do Trabalho com ênfase dos direitos e deveres do trabalhador, e para que um trabalho tenha sentido, o profissional deve, dentre outros aspectos, cumprir os deveres para com a sociedade (MOW, 1987). Haja vista que se o contador não consegue perceber a forma com que o produto do seu trabalho contribui para com a sociedade, ele não consegue fazer com que o trabalho seja repleto de sentido.

\section{CONCLUSÕES}

As discussões desta pesquisa referem-se ao trabalho do contador realizado em Instituições Federais de Ensino de Santa Catarina (IFE/SC). As respostas analisadas foram organizadas em três blocos: no primeiro, tratou-se das questões quanto à formação dos contadores e o tempo de atuação nas IFE/SC; no segundo, contemplou-se o trabalho do contador e o desenvolvimento profissional e no terceiro, evidenciou-se a percepção dos respondentes quanto à importância da contabilidade para a instituição e para a participação do contador na gestão e na sociedade.

Em relação à contabilidade os dados apresentados apontam para uma visão centrada em 'como fazer' em detrimento do 'porque fazer'. Esse entendimento perpetua-se na forma como os contadores descrevem o trabalho realizado, ao relatarem as atividades desempenhadas ressaltam a forte presença de uma rotina de trabalho e de atividades voltadas à execução. Esses aspectos são indicativos de um trabalho mecanizado, repetitivo cuja premissa está centrada na individualização das atividades e não na compreensão de todo o processo de trabalho. Apesar da ênfase no trabalho mecanizado, os contadores consideram o trabalho realizado gratificante e importante para a instituição, as respostas evidenciam o sentido que ele possui para os contadores.

Ainda em relação ao trabalho desempenhado, os pesquisados apontaram o conhecimento técnico e a ética como atributos essenciais ao trabalho de contador nas IFE/SC. Quanto à ética 82,85\% relataram que ela está integrada ao trabalho executado. Destaca-se ainda que a dicotomia entre a teoria e a prática contábil é uma característica marcante nas atividades desempenhadas pelos contadores, indicando insatisfação na apropriação do trabalho.

Quanto ao desenvolvimento profissional as respostas apontam a formação continuada centrada em práticas da rotina de trabalho, portanto, as atualizações obtidas pelos pesquisados estão voltadas à transmissão do conhecimento não havendo indicadores que demonstrem alteração na maneira de produzir o trabalho. Cabe enfatizar que a maior parte deles avalia o desenvolvimento profissional como bom e 
acredita estar em constante desenvolvimento. Entretanto, esse desenvolvimento aparece nas respostas vinculadas à atualização de normas, leis e regulamentos. Com isso, verifica-se que a rotina e a operacionalidade tomam corpo do trabalho como sentido de reprodução desse.

Em relação à interação da contabilidade e do trabalho do contador com a instituição e a sociedade, há predominância das respostas que relatam que a contabilidade possui pouco espaço na instituição. Entretanto, as demais respostas que caracterizaram o espaço da contabilidade na IFE como mediano e de grande importância evidenciam um processo de mudança nos ambientes institucionais, haja vista que a prática contábil ainda obedece às prescrições de resultados não há indicativos de mudanças na rotina de trabalho.

Quanto à relação das atividades realizadas pelo contador e a contribuição para o desenvolvimento institucional, a percepção dos pesquisados é que as atividades contribuam para a tomada de decisão da gestão. Desse modo, verifica-se que os profissionais compreendem o produto do trabalho realizado e os benefícios reais desse para as instituições.

Destaca-se ainda que apesar de o contador compreender o produto do seu trabalho para a instituição ainda há a dificuldade para a classe compreender o alcance desse para a sociedade, e isso impacta quanto ao valor que ele alcança para esse profissional. Assim, se o contador não percebe a forma com que o produto do seu trabalho contribui para com a sociedade, ele não faz com que seu trabalho seja significativo.

Por fim este estudo não esgota as possibilidades de discussões sobre o trabalho do contador em Instituições Federais de Ensino, visto que a partir dela indicam-se possibilidades de abordar a categoria trabalho aqui apresentada, considerando outros aspectos e particularidade. Para sugestão de trabalhos futuros, essa pesquisa poderá ser replicada em outras instituições federais de ensino localizadas nas demais regiões geográficas do Brasil.

\section{REFERÊNCIAS}

ALMEIDA, F. S.; FAVARIN, A. M.. Sistemas de Informações Gerenciais: o ambiente empresarial e o perfil do profissional de contabilidade. In: CONGRESSO USP DE CONTABILIDADE E CONTROLADORIA, 7. Anais. São Paulo: USP, 2007.

ALVES, F. J. S.; LISBOA, N. P.; WEFFORT, E. F. J.; ANTUNES, M T. P.. Um estudo empírico sobre a importância do código de ética profissional para o contabilista. Revista Contabilidade \& Finanças, São Paulo, v.18, p.58-6, 2007. DOI: https://doi.org/10.1590/S1519-70772007000300006

ANTUNES, R.. Os sentidos do trabalho: ensaio sobre a afirmação e a negação do trabalho. 3 ed. São Paulo: Boitempo, 2000.

ARAÚJO, R. R.; SACHUK, M. I.. Os sentidos do trabalho e suas implicações na formação dos indivíduos inseridos nas organizações contemporâneas. Revista de Gestão USP, São Paulo, v.14, n.1, p.53-66, 2007.

BARDIN, L.. Análise de conteúdo. Lisboa: edições, 2009.
BIASIBETTI, A. P.; FEIL, A. A.. Análise do perfil do profissional contábil requerido pelas empresas do Vale do Taquari-RS. Revista Destaques Acadêmicos, v.9, n.1, 2017.

BITTENCOURT, A. B.. Sobre o que falam as coisas lá fora: formação continuada dos profissionais da educação. In: FERREIRA, N. S. C.. Formação Continuada e Gestão da Educação. São Paulo: Cortez, 2006. p.65-94.

BLANCH, J. M.. Trabajar en la Modernidad Industrial. In: J. M. B.. Teoría de las Relaciones Laborales: fundamentos. Barcelona: UOC, 2003. p.19-148.

BRANDALISE, F.; FELLA, L. J.; ZAMIN, L. M.. O Contador público no contexto da gestão pública. Revista de Administração e Ciências Contábeis do IDEAU, v.4, n.8, p.2$17,2009$.

BRASIL. Decreto n.20.158. Organiza o ensino comercial, regulamenta a profissão de contador e dá outras providências. Brasília, 1931. 
BRASIL. Decreto-Lei n. 9.295. Cria o Conselho Federal de Contabilidade, define as atribuições do Contador e do Guarda-livros, e dá outras providências. Brasília, 1946.

BRASIL. Lei n. 4.320. Estatui normas gerais de direito financeiro para e laboração e controle de balanços da União, dos Estados, dos Municípios e do Distrito Federal. Brasília, 1964.

BRASIL. Lei n. 11.091. Dispõe sobre a estruturação do Plano de Carreira dos Cargos Técnico-Administrativos em Educação, no âmbito das Instituições Federais de Ensino vinculadas ao Ministério da Educação, e dá outras providências. Brasília, 2005.

BRASIL. Lei n. 12.249. Altera o Decreto-Lei n. 9.295, de 27 de maio de 1946. Brasília, 2010.

BRASIL. Resolução n. 10. Institui as Diretrizes Curriculares Nacionais para o Curso de Graduação em Ciências Contábeis, bacharelado, e dá outras providências. Brasília, 2004.

CAPACCHI, M.; MORETTO, C. F.; VANCIN, V.; PADILHA, F. A. R.. A prática do ensino contábil no Estado do Rio Grande do Sul: uma análise da grade curricular frente às exigências legais e necessidades acadêmicas. In: CONGRESSO ANPCONT, 1. Anais. Gramado: ANPCONT. 2007.

CAPRONI NETO, L. H.. Análise do significado e dos sentidos do trabalho para os funcionários do setor contábil-financeiro de uma IES pública. In: CONGRESSO VIRTUAL BRASILEIRO DE ADMINISTRAÇÃO, 9. Anais. CONVIBRA, 2012.

CARDOSO, J. L.; SOUZA, M. A.; ALMEIDA, L. B.. Perfil do Contador na atualidade: um estudo exploratório. BASE Revista de Administração e Contabilidade da Unisinos, São Leopoldo, v.3, n.3, p.275-284, 2006.

COELHO, C. U. F.. O ensino superior de contabilidade e o mercado de trabalho: uma análise no município do Rio de Janeiro. Pensar contábil. Rio de Janeiro, v.4, n.11, 2001.

CFC. Conselho Federal de Contabilidade. Resolução CFC $\mathbf{n}$. 560. Dispõe sobre as prerrogativas profissionais de que trata o artigo 25 do Decreto-Lei no 9295, de 27 de maio de 1946. Brasília, 1983.

COUTINHO, M. C.. Sentidos do Trabalho Contemporâneo: As Trajetórias Identitárias como Estratégia de Investigação. Cadernos de Psicologia Social do Trabalho, v.12, n.2, p.189202, 2009.

DEMO, P.. Metodologia do conhecimento científico. São Paulo: Atlas, 2000.
GIL, A. C.. Como elaborar projetos de pesquisa. 5 ed. São Paulo: Atlas, 2010.

HACKMAN, J.; OLDHAN, G.. Development of job diagnostic survey. Journal of Applied Psychology, v.60, n.2, p.159-170, 1975.

KRAEMER, M. E. P.. Reflexões sobre o ensino da Contabilidade. Revista Brasileira de Contabilidade, n.153, p. 64-79, 2005.

MARIN, T. I. S.; LIMA, S. J.; CASA NOVA, S. P. C.. Formação do Contador - o que o Mercado quer, é o que ele tem? Um Estudo sobre o Perfil Profissional dos Alunos de Ciências Contábeis da FEA-USP. Contabilidade Vista \& Revista, Belo Horizonte, v.25, n.2, p.59-83, 2014.

MIGLIACCIO FILHO, R.. Reflexões sobre o homem e o trabalho. Revista de Administração de Empresas, São Paulo, v. 34, n.2, p.18-32, 1994.

MOW. Meaning of Work International Research Team. The meaning of working. London: Academic Press, 1987.

OLIVEIRA, C. R.; GOMES, G.; RAUSCH, R. B.; CUNHA, P. R.. Aproximações entre o perfil do contador desejado pelo mercado e as matrizes curriculares de cursos de graduação em ciências contábeis, Revista Eletrônica de Ciências da Educação, Campo Largo, v.10, n.1, p.47-68, 2011.

SILVA, M. R.. Contribuição à melhoria da atuação profissional do contador da cidade de São Paulo: pesquisa face às exigências do mercado de trabalho. Dissertação (Mestrado em Ciências Contábeis) - Faculdade Escola de Comércio Álvares Penteado, São Paulo, 2003.

SLOMSKI, V. G.; GOMES, S. M. S.; SILVA, A. C. R.; GUIMARÃES, I. P.. Mudanças Curriculares e qualidade de ensino: ensino com pesquisa como proposta metodológica para a formação de contadores globalizados. Revista de Contabilidade e Organizações, São Paulo, v.4, n.8, p. 160$188,2010$.

TOLFO, S. R; PICCININI, V.. Sentidos e significados do trabalho: explorando conceitos, variáveis e estudos empíricos brasileiros. Psicologia \& Sociedade, Porto Alegre, v.19, n. spe, p.38-46, 2007.

TONIN, J. M. F.; ARANTES, V. A.; JUANIHA, A. M.; COLAUTO, R. D.. Estereótipos e habilidades do Contador: confronto entre a cinematografia e a realidade. In: CONGRESSO INTERNACIONAL DE CONTABILIDADE E AUDITORIA, 16. Anais. Aveiro, 2017.

A CBPC - Companhia Brasileira de Produção Científica (CNPJ: 11.221.422/0001-03) detém os direitos materiais desta publicação. Os direitos referem-se à publicação do trabalho em qualquer parte do mundo, incluindo os direitos às renovações, expansões e disseminações da contribuição, bem como outros direitos subsidiários. Todos os trabalhos publicados eletronicamente poderão posteriormente ser publicados em coletâneas impressas sob coordenação da Sustenere Publishing da Companhia Brasileira de Produção Científica e seus parceiros autorizados. Os (as) autores (as) preservam os direitos autorais, mas não têm permissão para a publicação da contribuição em outro meio, impresso ou digital, em português ou em tradução. 